\title{
Н.М. Жабіна
}

\section{ВЕРХНІЙ ТИТОН ТЕТИЧНОЇ ПРОВІНЦІЇ: ЗОНАЛЬНІСЬ ТА КОРЕЛЯЦІЯ ЗА ТИНТИНІДАМИ}

Наведено критерії зонального розчленування відкладів верхнього титону (верхня юра) за тинтинідами у розрізах Франції, Австрії, Словаччини, Польщі, України, Болгарії, Румунії, Куби, Італії, Грузії. У регіонах Середземноморського поясу виділено зони тинтинід Chitinoidella (підзони Dobeni i Boneti), Praetintinnopsella i Crassicollaria, які охарактеризовано за літературними джерелами. За кореляцією 3 сучасними магнітостратиграфічною та зональною амонітовою шкалами підзона Dobeni відноситься до перехідних верств нижнього і верхнього титону (амонітових зон Ponti та Microcantum), a Boneti - до нижньої частини верхнього титону (нижня половина зони Microcantum), зона Praetintinnopsella залягає у нижніх верствах верхнього титону, зона Crassicollaria відповідає інтервалу амонітових зон - верхній частині зони Micracanthoceras microcanthum, зоні Durandites і нижній частині зони Berriasella Jacobi. У більшості регіонів визначено лише зону Crassicollaria, але критерії виділення та поділу її відрізняються. Суттєвою підставою для визначення підошви зони є різке зменшення кількості хітиноіделід та збільшення різноманіття і кількості кальпіонелід, серед яких у зональному комплексі домінують представники роду Crassicollaria, а також Tintinnopsella carpathica i Calpionella alpina. У покрівлі зони зменшується різноманіття кальпіонелід, серед яких домінують дрібні Calpionella alpina, кількість яких різко зростає у підошві беріасу. У верхньому титоні Передкарпатського прогину України виділено зони Chitinoidella (підзони Dobeni, Boneti) і Crassicollaria (Remanei, Intermedia). Зміна зональних асоціацій у цих відкладах відбувається поступово, коли у більш молодих підрозділах присутні елементи більш давніх. Так, характерні види зони Chitinoidella майже зникають до кінця підзони Remanei, яка характеризується асоціацією Tintinnopsella carpathica, T. remanei, різних Crassicollaria і переважно дрібних Calpionella alpina. У підзоні Intermedia зростає кількість та різноманіття кальпіонелід, збільшується частка великих округлих C.alpina, з'являються види, типові для беріасу. Характерні для зони кальпіонеліди переходять у більш молоду зону Calpionella, в підошві якої відбувається розквіт C. alpina. Наведено докладну характеристику опорного розрізу зони Crassicollaria в Україні.

Ключові слова: тинтиніди, зональні підрозділи, кореляція, верхній титон, Середземноморський пояс, Карпати України.

Вступ. У Стандартній зональній схемі за тинтинідами Середземноморського поясу, прийнятій на II Планктонній конференції (Рим, 1970 р.) [Remane et al., 1986] та удосконаленій в подальшому, виділено три зони титону - Chitinoidella, Praetintinnopsella, Crassicollaria. В Україні ці зони визначено лише у Пенінській зоні Карпат та Передкарпатському прогині. У статті наведено критерії зонального розчленування відкладів верхнього титону провінції Тетісу, а також результати досліджень тинтинід у Карпатському регіоні України. Кореляція відкладів за тинтинідами, амонітами та даними магнітостратиграфії дала змогу деталізувати характеристику зональних підрозділів верхнього титону за тинтинідами.

Матеріали та методи досліджень. Результати досліджень ґрунтуються на вивченні тинтинід у шліфах 3 керна свердловин, пробурених на північному заході Передкарпатського прогину, та аналізі великого обсягу даних, отриманих дослідниками в інших регіонах.

Поряд з результатами власного вивчення тинтинід і форамініфер у Передкарпатті, враховані дані літолого-петрографічного аналізу (Л.В. Лінецька, О.В. Самарська), діагностики тинтинід (Л.В. Лінецька), фрорамініфер (В.Г. Дулуб), динофлагелят (Л.В. Лінецька, О.В. Самарська). Для кореляції відкладів та уточнення віку зональних підрозділів за тинтинідами використані опубліковані результати палеомагнітних досліджень у розрізах Словаччини, Польщі, Австрії.

(c) Н.М. Жабіна, 2016 
Загальна характеристика стандартних тинтинідових зон верхнього титону. Зону Chitinoidella (Borza K., 1969) простежно у Словаччині, Польщі, Україні, Румунії, Болгарії, Італії, Іспанії, Туреччині, Мексиці, на Кубі, Кавказі та Аравійському півострові. В Українському Передкарпатті та на Кавказі зону виділено в обсязі оксфрорду - початку пізнього титону у складі трьох підзон. В інших регіонах виявлено лише підзони титону Dobeni (перехідні верстви нижнього і верхнього титону, амонітових зон Ponti та Microcantum) i Boneti (верхній титон, нижня половина зони Microcantum) [Жабіна, 2014].

Зона виділяється за комплексом, у складі якого переважають хітиноіделіди Chitinoidella, Dobeniella, Borziella, Almajella, присутні семіхітиноіделіди - Praetintinnopsella, Durandella, численні мікрогранулярні кальпіонеліди - Foliacella, Rossiella, Borzaiella, Scalpratella та поодинокі гіалінові - Crassicollaria.

У верхніх підзонах титону серед хітиноіделід з'являються представники Longicollaria, Dobeniella, Daciella, Carpatella, Durandella. У підзоні Dobeni домінують Longicollaria dobeni (Borza), у підзоні Boneti переважають Chitinoidella boneti Doben, з'являються Рорiella oblongata Rehakova, Chitinoidella elongata Pop, C. lubimovae Furasolla-Bermudez et Kreisel, Semichitinoidella durandelgai Nowak, S. suikowskii Nowak [Жабіна, 2014].

Зону Praetintinnopsella (Grandesso, 1977) було визначено для заходу Тетичної палеопровінції на межі середнього і верхнього титону. Ї̈ простежено у Карпатах Словаччини (Michalik J., 1994 та ін.), Румунії (Pop G., 1974 та ін.), Татрах Польщі (Grabowski J., 2006), Балканідах Болгарії (Lakova J., 1993 та ін.), Альпах Австрії (Rehakova D. et al., 2009 та ін.), в Іспанії (Oloriz F. et al., 1995), Італії (Grandesso P., 1977). Аналогічну зону Semichitinoidella-Praetintinnopsella визначено у Карпатах Польщі (Nowak W., 1978) та в Грузії (Тодриа В.А., 1999). За кореляцією 3 магнітостратиграфічною шкалою зона залягає у нижніх верствах верхнього титону [Grabowski, Pszczolkowski, 2006].

У різних регіонах зону визначають по-різному: як інтервал повного поширення видуіндексу Praetintinnopsella andrusovi Borza, або за першою появою тинтинід з двошаровою стінкою; нижню ії границю проводять за зникненням хітиноіделід та появою індексу, верхню границю - за зникненням цього виду та появою кальпіонелід Crassicollaria i Tintinnopsella. Зональний комплекс визначено як моноасоціацію індексу, подекуди 3 Semichitinoidella durandelgai та S. sujkowskii. У Польських Татрах в зоні виявлено також хітиноіделіди та поодинокі Praetintinnopsella sp. [Grabowski., Pszczolkowski, 2006]. У Середній Азії та на Кавказі перша поява виду Praetintinnopsella andrussovi зафріксована ще у келовеї та оксфорді [Долицкая, 1983; Макарьева, 1979], а у Передкарпатті України та на Північному Кавказі цей вид поширений від оксфорду до верхів титону [Макарьева, 1979; Жабіна, 2014]. Отже, критерії виділення зони Praetintinnopsella на теперішній час не однозначні.

Зону Crassicollaria (Remane, 1963) вперше було встановлено у верхньому титоні Північно-Східної Франції як інтервал А і переведено в ранг стандартної зони на II Планктонній конференції (Рим, 1970). Ії̈ простежено у Карпатах Словаччини (Vasicek Z. et al., 1992 та ін.), Польщі (Nowak W., 1978; Olszewska B., 2005), України (Лінецька Л.В., 1972; Жабіна H.M., 2008), Румунії (Рор G., 1974 та ін.), Альпах Австрії (Rehakova D. et al., 2009 та ін.), Балканідах Болгарії (Lakova J., 1993 та ін.), на Північному Кавказі (Макарьєва С.Ф., 1979), Кубі (Pop G., 1976), в Канаді (Ascoli P. et al., 1984), Мексиці (Trejo М., 1975), Італії (Andreini G. et al., 2007) та інших регіонах. У цих відкладах зону визначено як акме-зону роду Crassicollaria, нижню границю - за появою асоціацій гіалінових кальпіонелід 3 домінуванням різноманітних красиколярій, верхню - за бурхливим розквітом Calpionella alpina Lorenz. У підошві зони кальпіонеліди нечисленні. У деяких регіонах встановлено, що першими у зоні з'являються дрібні Tintinnopsella carpathica (Murgeanui et Filipescu), відразу ж за ними - різноманітні Crassicollaria. До кінця зони зникли Crassicollaria brevis Remane (форми короткі), C. intermedia Durand Delga (довгі), C. massutiniana (Colom) (середні). Одночасно зі зменшенням кількості C. intermedia з'явились видовжені фрорми Calpionella, які також зникли у покрівлі зони. Після цього дещо зросла кількість Crassicollaria parvula Remane (маленькі фрорми) і з'явились маленькі сферичні фрорми Calpionella alpina, які відрізняються від титонських форм маленькими розмірами, більш 
короткою камерою, дещо вужчим оральним отвором і більш довгим комірцем. Поряд 3 Tintinnopsella carpathica останні два види продовжили існувати у беріаській зоні Calpionella, на початку якої відбувся раптовий розквіт роду Calpionella [Housa, 1990].

У Франції зону поділено (Remane, 1963, 1964) на три інтервали - A1, A2, A3: для A1 найбільш характерні Crassicollaria intermedia, A2 - C. massutiniana, C. brevis, Calpionella alpina, A3 - C. parvula. У покрівлі ці красиколярії зникають, в самому кінці зони з'являються Calpionella elliptalpina Nagy [Le Hegarat, Remane, 1968 та ін.]. Пізніше ці інтервали переведено у ранг підзон. Проте, критерії поділу зони у різних регіонах різні (рис. 1,2$)$.

На II Планктонній конференції (Рим, 1970) прийнято двочленний поділ зони: нижня підзона Remaneі (відповідає інтервалу А1) - ассоціація Crassicollaria intermedia, Tintinnopsella carpathica, T. remanei, у покрівлі з'являється Crassicollaria massutiniana. Верхня - підзона Intermedia (об'єднує А2 і А3) - ассоціація C. intermedia, C. brevis, C. parvula, C. gr. intermedia -massutiniana, Calpionella alpina, Tintinnopsella carpathica.

\begin{tabular}{|c|c|c|c|}
\hline Регіони & \multicolumn{2}{|c|}{ Підрозділи зони Crassicollaria } \\
\hline $\begin{array}{c}\text { Інтервали за Ю. Ремане } \\
\text { (Франція південно-західна) }\end{array}$ & $\mathrm{A} 1$ & $\mathrm{~A} 2$ & А3 \\
\hline Римський стандарт & Remanei & \multicolumn{2}{|c|}{ Intermedia } \\
\hline Західні Карпати Словаччини & Remanei & Brevis & Intermedia \\
\hline Західні Карпати Польщі & Remanei & Brevis-Parvula \\
\hline Південні Карпати Румунії & Intermedia & Massutiniana \\
\hline Західні Балканіди Болгарії & Remanei & Intermedia \\
\hline Західна Сицилія & Remanei & Intermedia \\
\hline Австрійські Альпи & Remanei & Intermedia \\
\hline Куба & & Intermedia-Brevis \\
\hline Північний Кавказ & & Brevis \\
\hline Українські Карпати & Remanei & Intermedia \\
\hline Передкарпаття України & Remanei &
\end{tabular}

Рис.1. Підрозділи зони Crassicollaria у регіонах Тетичної провінції

У Південних Карпатах виділено (G. Рор, 1974, 1976) підзони Intermedia (відповідає інтервалу A1) i Brevis-Parvula (об'єднує A2 і A3) за домінуванням індексів.

У Західних Балканідах виділено (Lakova J., 1993 та ін.) дві підзони - Remanei (відповідає A1) і Massutiniana (об'єднує A2 і А3). У підошві Remanei сумісно з'являються C. intermedia, Tintinnopsella carpathica, T. remanei Borza. Підзона Massutiniana відповідає стратиграфрічному інтервалу Crassicollaria massutiniana (з'явились у покрівлі нижньої підзони), підошва визначається за появою Calpionella grandalpina Nagy і Calpionella alpina; лише у цій підзоні присутні Crassicollaria brevis і C. parvula (з'являються дещо пізніше). У покрівлі зони востаннє присутні Calpionella ellipthalpina, що збігається з розквітом Calpionella alpina.

У Західних Карпатах виділяють (Michalik J., 1994 та ін.) три підзони: Remanei (відповідає інтервалу А1), Brevis (A2) і Colomi (A3). У підзоні Remaneі домінують Crassicollaria intermedia (поширені лише у цій підзоні), у підошві з'являються маленькі Tintinnopsella carpathica, а з покрівлі - Calpionella grandalpina. Brevis і Colomi відповідають стратиграфічному поширенню індексів. У підзоні Brevis асоціація різноманітна з великими подовженими C. grandalpina та чисденними Crassicollaria massutiniana.

Пізніше нижній інтервал зони (A1) визначили як підзону Remanei, а підзони Brevis i Colomi об'єднали у підзону Intermedia, яка відповідає підзоні Massutiniana (за Lakova, 1993) і Brevis-Parvula (Рop, 1974). У нижній підзоні домінують Crassicollaria intermedia, у верхній - Calpionella grandalpina, а кількість Crassicollaria massutiniana помірна.

У Татрах Польщі визначено підзону Intermedia за асоціацією Tintinnopsella carpathica, численних Crassicollaria intermedia, C. massutiniana, C. brevis (кількість зростає 
у верхній частині), C. parvula (у нижній частині), Calpionella alpina [Grabowski, Pszczolkowski, 2006].

На Кубі також виділено підзону Intermedia, у якій домінують Calpionella alpina, присутні Crassicollaria intermedia, C. brevis, C. parvula, C. gr. intermedia-massutiniana, Crassicollaria sp., Remaniella sp., Tintinnopsella sp., у покрівлі з'являються T. carpathica, а у деяких розрізах зафріксовано домінування C. brevis (Pszczolkowski A. et al., 2005).

У Західній Сицилії визначено дві підзони (Andreini G. et al., 2007). У підзоні Remanei, яка згідно перекриває зону Chitinoidella, виявлено першу асоціацію 3 гіаліновими тинтинідами, представленими дрібними Calpionella alpina i Tintinnopsella carpathica, a також T. remanei, Crassicollaria intermedia, C. brevis. У підзоні Intermedia різко зростає кількість (до 70\%) і різноманіття тинтинід, серед яких домінують Calpionella; у підошві вперше з'являються великі Calpionella alpina, перехідні форми Calpionella alpina-elliptica. Присутні також Calpionella sp., різноманітні Crassicollaria - C. intermedia, C. massutiniana, C. brevis, C. parvula, C. colomi i Tintinnopsella carpathica (кількість зменшується догори). У середній частині діагностовано також маленькі сферичні Calpionella alpina.

В Австрії підзона Remanei характеризується моноасоціацією Tintinnopsella remanei, а підзона Intermedia - комплексом Calpionella alpina, Tintinnopsella carpathica, Crassicollaria parvula, у нижній частині з C. massutiniana, Calpionella grandalpina (Rehakova D. et al., 2009 та ін.).

Зону Crassicollaria визначено також на Кавказі (С.Ф. Макарьєва,1979), де виділено підзону Intermedia-Brevis. За даними С.Ф. Макарьєвої, у підошві вперше з'являються Tintinnopsella remanei, Crassicollaria intermedia, C. brevis, C. parvula, C. massutiniana, Lorenziella transdanubica Knauer et Nagy, більшість з яких численні у зоні. Домінують перші три види разом з Tintinnopsella carpathica. Нечисленні Crassicollaria massutiniana, C. remanei, C. colomi Boller, Durandella cf. helentappani Drag., Cassicollaria sp., Calpionella alpina. До кінця зони зникають - Dobeniella cubensis (Furasolla-Bermudez), D. colomi (Borza), Borziella slovenica (Borza), Praetintinnopsella andrusovi. У верхній частині з'являються Remaniella ferasini Catalano. Характерний комплекс зони Crassicollaria за даними В. Тодріа - Calpionella alpina, C. elliptica Cadish, Crassicollaria brevis, C. colomi, C. intermedia, C. massutiniana, C. parvula, Tintinnopsella carpathica, T. colomi Boller, у низу - T. remanei, тут з'являються T. doliphormis, Remaniella cadishiana (Colom), Calpionellopsis oblonga (Cadish), Calpionellites darderi (Colom), Amphorellina lanceolata Colom [Макарьева, 1979 та ін.].

Отже, більшість дослідників зону Crassicollaria поділяють на дві підзони: нижню підзону (відповідає інтервалу А1) виділено у Західних Карпатах, Західних Балканідах, Альпах, Сицилії як підзону Remanei, у Південних Карпатах - Intermedia, а верхню підзону (інтервали А2 і А3) визначено у Татрах, Альпах, Сицилії, на Кубі як Intermedia, у Південних Карпатах - Brevis-Parvula, у Західних Балканідах - Massutiniana. Лише у Західних Карпатах встановлено три підзони, які відповідають трьом інтервалам, встановленим у Франції. Підошву зони встановлюють за появою Tintinnopsella carpathica, T. remanei, Crassicollaria intermedia. Верхню підзону в багатьох регіонах виділяють за появою C. massutiniana, C. brevis, C. parvula, Calpionella alpina, C. grandalpina. На Кавказі зональна асоціація відрізняється. Тут перші кальпіонеліди діагностовано у зоні Chitinoidella (Crassicollaria intermedia, Calpionella alpina, Tintinnopsella carpathica - у підзоні Ch2), а у зоні Crassicollaria поряд з численними красиколяріями трапляються хітиноіделіди, а також з'являються типові для крейди Remaniella ferasini, Calpionella elliptica, Tintinnopsella colomi, T. doliformis, Calpionellopsis oblonga, Calpionellites darderi (рис. 2).

За магнітостратиграфічними дослідженнями розрізів титону Словаччини, Італії та Іспанії виявлено дві короткочасні магнітні інверсії, за якими виділено реверсні магнітопідзони - Кисуца (Kysuca) і Бродно (Brodno) [Housa et al., 1999; 2004 та ін.].

У Західних Карпатах підошву зони Crassicollaria проведено дещо нижче підошви магнітопідзони Кисуца, покрівлю підзони Remanei - під підошвою магнітозони М19, а покрівлю Intermedia - на рівні 40\% потужності частини під Бродно зони M19 [Housa et al., 1999]. 


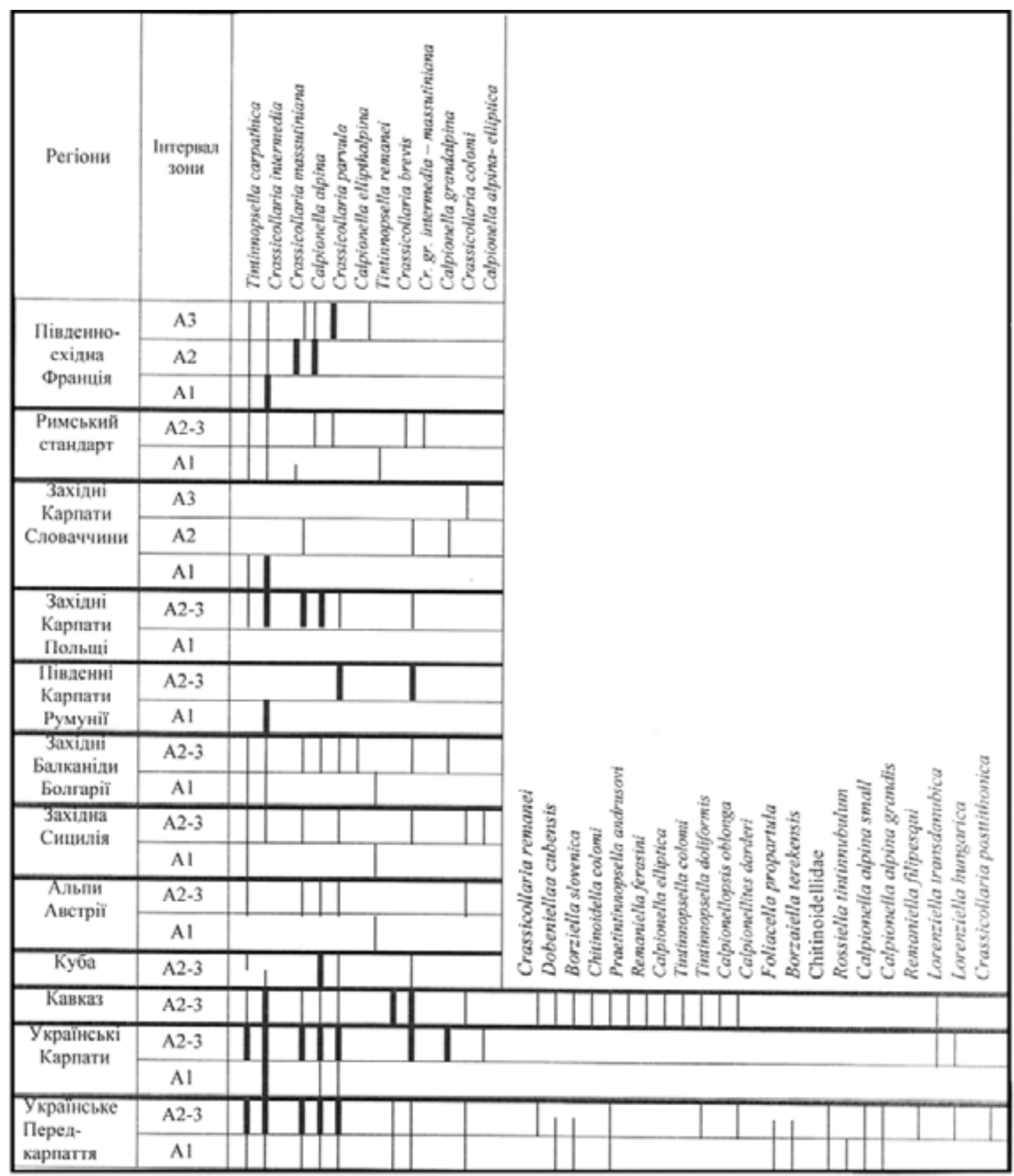

Рис. 2. Розподіл тинтинід у підрозділах зони Crassicollaria в регіонах Тетісу.

В Австрії покрівлю зони Chitinoidella визначено у верхах магнітопідзони Кисуца, а підошву зони Crassicollaria - посередині частини зони M20 над реверсною підзоною Кисуца. Між цими рівнями виділено інтервал зони Praetintinnopsella. Підзона Remanei займає 1/5 частини зони M20 над реверсною підзоною Кисуца. Покрівля Crassicollaria проводиться приблизно посередині частини зони М19 під реверсною підзоною Бродно [Lukeneder et al., 2010].

У Польських Татрах підошву зони Crassicollaria визначено посередині магнітозони M20, а границю зон Crassicollaria i Calpionella - в частині магнітозони M19 під Бродно 
[Grabowski, Pszczolkowski, 2006]. В інших регіонах цю границю визначено біля границі магнітозон M19 і M18 [Wimbledon et al., 2011].

Відповідно до сучасних даних, верхня границя зони Crassicollaria відповідає середній частині магнітозони M19n [Wimbledon, 2016].

Зіставлення цих даних показує, що стратиграфічний діапазон зони Crassicollaria відповідає інтервалу від верхньої частини магнітозони M20 до середини підзони М19n. Відповідно до Міжнародної шкали геологічного часу (Gradstein et al., 2012) цей обсяг відповідає інтервалу амонітових зон: верхня частина зони Microcanthum, зона Durandites i нижні верстви зони Jacobi.

Характеристика зони Crassicollaria в Українському Передкарпатті. На території України зону Crassicollaria вперше виділено Л.В. Лінецькою (1983 р.) у Передкарпатті - у розрізі, розкритому свердловиною Кароліна-6 в інтервалі глибин 2293-2372 м за наявністю асоціації численних Crassicollaria intermedia, C. massutiniana, C. brevis, поодиноких Calpionella alpina i Tintinnopsella carpathica [Линецкая, Лозыняк, 1983]. Притаманну цій зоні асоціацію кальпіонелід діагностовано Л.В. Лінецькою також у розрізі гори Великий Камінець Пенінської зони [Лінецька, 1972] та в Ужгород-Солотвинській зоні Закарпатського прогину у керні свердловин Добронь-1, Теребля-8, Сокирниця-3 (Л.В. Лінецька, 1973). Пізніше на горі Великий Камінець було виділено зону Crassicollaria з підзонами Remanei i Brevis [Rehakova et al., 2011]. Зональний комплекс у цьому розрізі - Calpionella alpina, C. elliptica, C. grandalpina, C. undelloides, Tintinnopsella carpathica, Crassicollaria massutiniana, C. parvula, C. brevis, Lorenziella hungarica, L. pseudoserrata [Лінецька, 1972]. У підзоні Remaneі домінують Crassicollaria intermedia над C. parvula і Calpionella alpina, вище - численні C. alpina, C. grandalpina, Crassicollaria massutiniana, C. parvula, C. brevis, C. intermedia, Tintinnopsella carpathica [Rehakova et al., 2011]. У Карпатах ці відклади належать до олістолітів.

B автохтонному заляганні зону Crassicollaria визначено на території Передкарпатського прогину (рис. 1) у розрізах, розкритих свердловинами Кароліна-6 (2390-2260 м), Моранці-1 (2335-2265 м), Південні Опари-1 (2679-2811 м), Грушів-8 (22302356 м), Подільці-1 (2200-2310 м), Волоща-1 (2215-2270 м) (рис. 3).

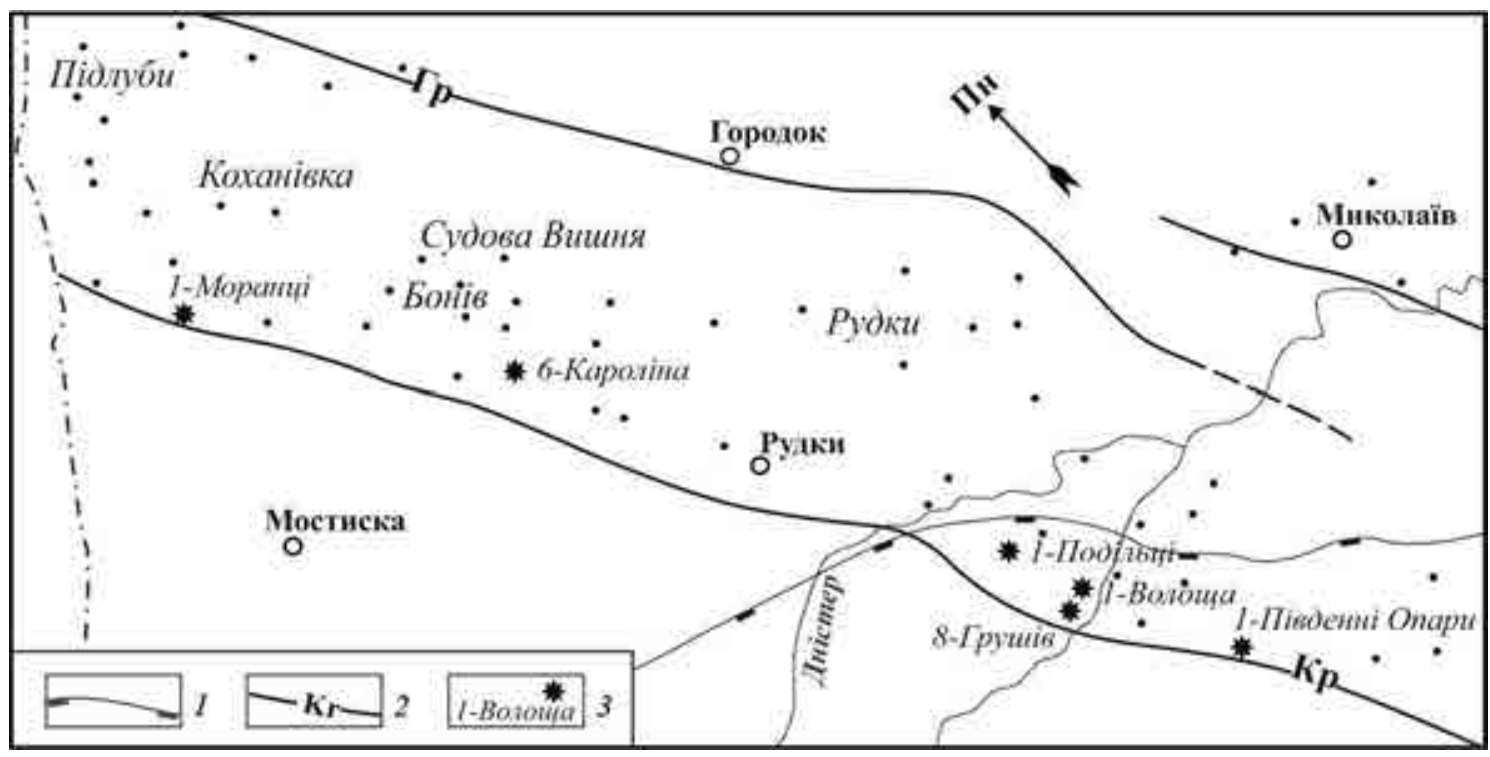

Рис. 3. Розташування свердловин, що розкрили зону Crassicollaria у Передкарпатському прогині

Найбільш повно зональний комплекс тинтинід представлено у керні свердловини Кароліна-6. Наші дослідження дали можливість уточнити інтервал зони, виділити в їі 
складі дві підзони (див. рис. 1, 2,.4). Нижню границю зони Crassicollaria визначено на глибині 2390 м, нижче якої за масовою присутністю Chitinoidella boneti виділено верхню підзону Boneti зони Chitinoidella.

Підзону Remanei розкрито на глибинах 2353-2390 м (рис. 3). Представлена вапняками кремовими і сірими, дрібноплямистими, мікритовими, біокластичними, прошарками брекчієподібними, онколітовими, темно-сірими глинистими. Породи міцні тріщинуваті, містять бітум, розсіяний кристалічний кальцит, черепашковий шлам. Брекчиєподібні вапняки слабо доломітизовані з криптокристалічною основною масою, ділянками грудкуватою, містять уламки вапняків, оолітів, лінзовидні ділянки окременіння, складні стилолітові шви, обкатані рештки фавреін, уривки клубковидних водоростей, фррагменти голкошкірих, планктонних криноідей, дрібні гастроподи. У цих відкладах присутні різноманітні кальпіонеліди - Crassicollaria brevis, C. aff. intermedia, C. colomi, C. aff. massutiniana, Crassicollaria sp., Tintinnopsella carpathica, дрібні сферичні та більш крупні Calpionella alpina, видовжені - Calpionella aff. elliptica, поодинокі Tintinnopsella sp., вперше з'являються T. remanei, Crassicollaria massutiniana, C. intermedia, C. parvula, Calpionella alpina grandis Doben. Разом 3 ними трапляються мікрогранулярні Borzaiella terekensis Makarjeva, Foliacella propartula Makarjeva, Rossiella tintinnubulum Makarjeva, хітиноіделіди - Chitinoidella boneti, Ch. elongata, Dobeniella cubensis, D. bermudezi (Furasolla-Bermudez), Daciella svinitensis Рop, семіхітиноіделіди Semichitinoidella cf. suikowskii Nowak, Praetintinnopsella andrusovi.

За характерними видами Tintinnopsella remanei, T. carpathica, Crassicollaria intermedia в асоціації з дрібними сферичними Calpionella alpina цей інтервал відповідає підзоні Remanei. У цих породах також присутні динофлагеляти - Cadosina fusca Wanner, C. semiradiata Wanner (поширені у верхній юрі та нижній крейді) та асоціація форамініфер верхнього титону - Quinqueloculina podlubiensis Terest., Trocholina molesta Gorb., T. alpina (Leup.), Coscinoconus conicus (Masl.), Nautiloculina oolithica Mochler, Verneuilina liasina Terquem et Berthelin, V. polonica (Cushm et Glaz.), Belorussiella cf. textularioides (Reuss) та ін.

Підзону Intermedia виділено в інтервалі 2293-2308 м. Представлена вапняками темно-сірими плямистими глинистими міцними перекристалізованими 3 кристалічним кальцитом тріщинуватими (часто з глиною), прошарками не глинистими мікритовими. Глинисті вапняки біокластичні 3 основною масою криптокристалічною, місцями мікрозернистою, дрібно грудкуватою, слабо доломітизованою, з гніздами і кристалами піриту, кальцитом, містять черепашковий шлам, фрагменти водоростей, глобохети, сфрери, голки їжаків, членики криноідей. У цих відкладах комплекс тинтинід змінюється. Тут трапляються поодинокі хітиноіделіди, мікрогранулярні кальпіонеліди, Praetintinnopsella andrusovi, спостерігається акме-зона красиколярій, представлених численними екземплярами Crassicollaria intermedia, C. parvula, C. massutiniana, C. brevis, подекуди C. colomi, C. posttithonica Nowak. У великій кількості також присутні Calpionella alpina (маленькі сореричні, великі округлі та подовжені), C. alpina grandis, а також наявні Tintinnopsella carpathica, T. remanei, Calpionella aff. elliptica. Тут вперше з'являються C. elliptica, Remaniella filipesqui Pop, Calpionellites darderi, більш притаманні відкладам крейди. Окрім тинтинід у цих породах присутня асоціація форамініфер верхнього титону Charentia compressa (Cushm. et Glaz.), Belorussiella taurica (Gorb.), Trocholina alpina, Discorbis cf. agalarovae Antonova, Quinqueloculina verbizhiensis Dulub, Q. podlubiensis Terestchuk, Gaudryina bukowiensis (Cushm. et Glaz.), Textularia crimica Gorb. та ін.

Покрівля зони Crassicollaria у цьому розрізі керном не охарактеризована. Вище в 2243-2261 м, у низах якого зафіксована різка зміна геофізичних показників порід, розріз представлено вапняками майже чорними на контакті 3 кремовими. Вапняки криптокристалічні, місцями мікритові, слабо доломітизовані, масивні, ділянками мікрошаруваті, містять черепашковий шлам, спікули губок, ділянки окременіння. Присутні прошарки силіцитів, строкатоколірних алевролітів з уламками вапняків. У цих вапняках асоціація тинтинід різко відрізняється своєю одноманітністю, представлена переважно численними дрібними сферичними Calpionella alpina. Подекуди трапляються Crassicollaria 
brevis, поодинокі Crassicollaria intermedia та з'являються Tintinnopsella doliformis. Такий комплекс притаманний нижнім верствам беріасу - підзоні Alpina зони Calpionella.

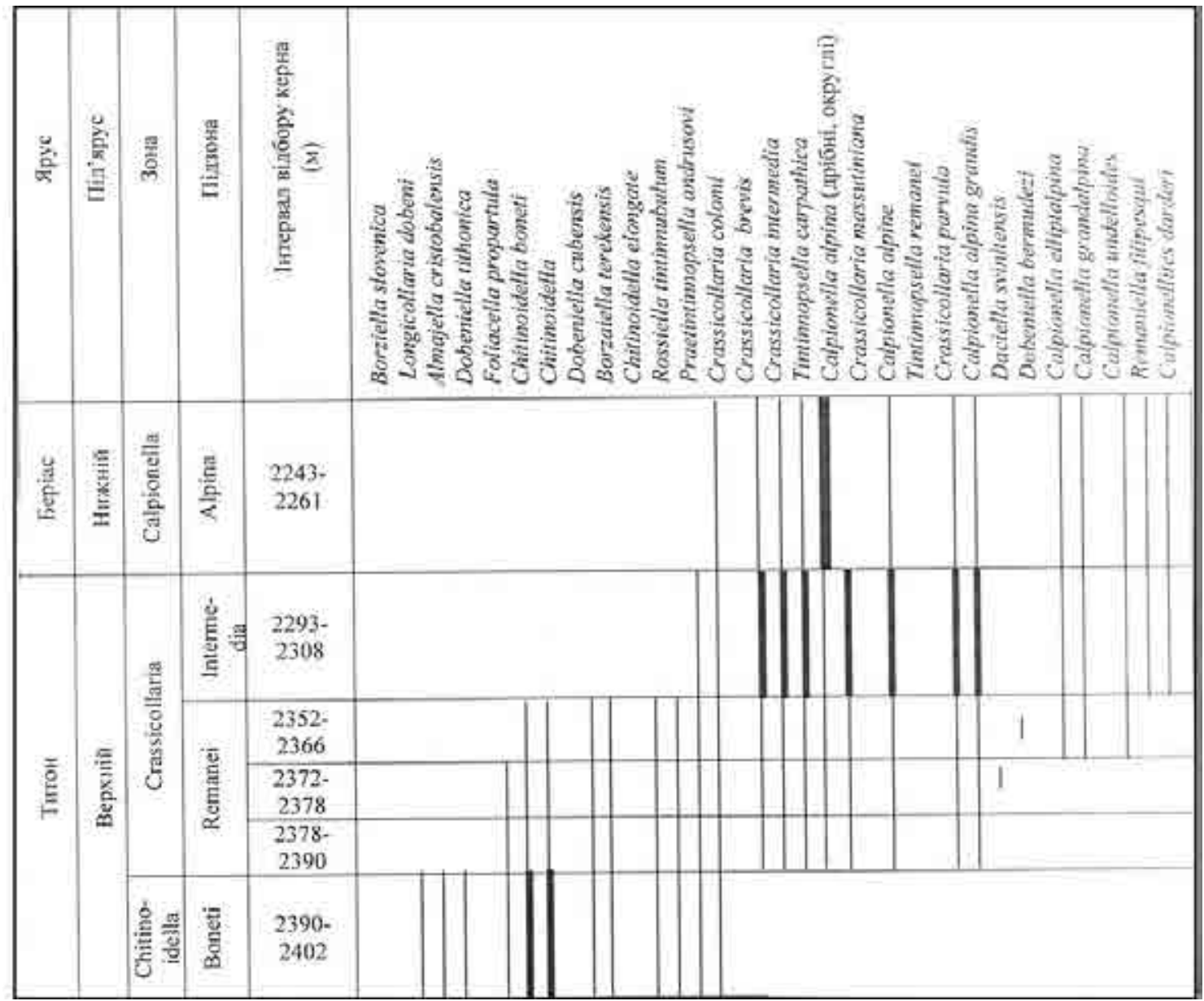

Рис. 4. Розподіл тинтинід в розрізі, розкритому свердловиною Кароліна-6

Майже безперервний розріз зони представлено керновим матеріалом свердловини Моранці-1 (рис. 5). Внаслідок діагенетичних процесів тинтиніди у вапняках не виразні, що унеможливило виявити зональний комплекс в повному обсязі. Проте у цьому розрізі охарактеризовано верхню частину зони Crassicollaria та її границю із зоною Calpionella.

По всій зоні поширені Crassicollaria colomi, поодинокі хітиноіделіди, Praetintinnopsella andrussovi. У підошві з'являються Tintinnopsella carpathica, T. remanei, Crassicollaria brevis, а дещо вище у підзоні Remanei - C.intermedia, Calpionella alpina. У цій підзоні трапляються види, характерні для зони Chitinoidella - Chitinoidella boneti, C. elongata Pop, Dobeniella cubensis, D. tithonica (Borza), Longicollaria cf. insueta (Rehanek), Rosiella tintinnubulum, Foliacella propartula, Borzaiella terekensis, Semichitinoidella suikowskii, Scalpratella angustioris Makarjeva, які зникають до кінця підзони. У підошві підзони Intermedia з'являються Tintinnopsella doliformis, Crassicollaria parvula, C. massutiniana, a дещо вище - C. remanei Makarjeva, Lorenziella hungarica, маленькі сферичні Calpionella alpina, кількість яких різко зростає у покрівлі зони.

Відклади верхнього титону також містять титонського віку комплекси диноцист Colomisphaera carpathica (Borza), C. tenuis (Nagy), C. lapidosa Vogler, C. radiata Vogler, Carpistomiosphaera borzai (Nagy), Parastomiosphaera malmica (Borza) і фрорамініфер - 
Pseudocyclammina lituus Yok., Charentia compressa, Orbignyoides podolicus (Cushm. et Glaz.), Quinqueloculina podlubiensis, Q. verbizhiensis, G. bukowiensis, Nautiloculina oolithica Mohler, Gaudryina althi (Cushm. et Glaz.), G. vadaszi (Cushm. et Glaz.), Trocholina elongata (Leup.), Protopeneroplis striata Weynshenk.

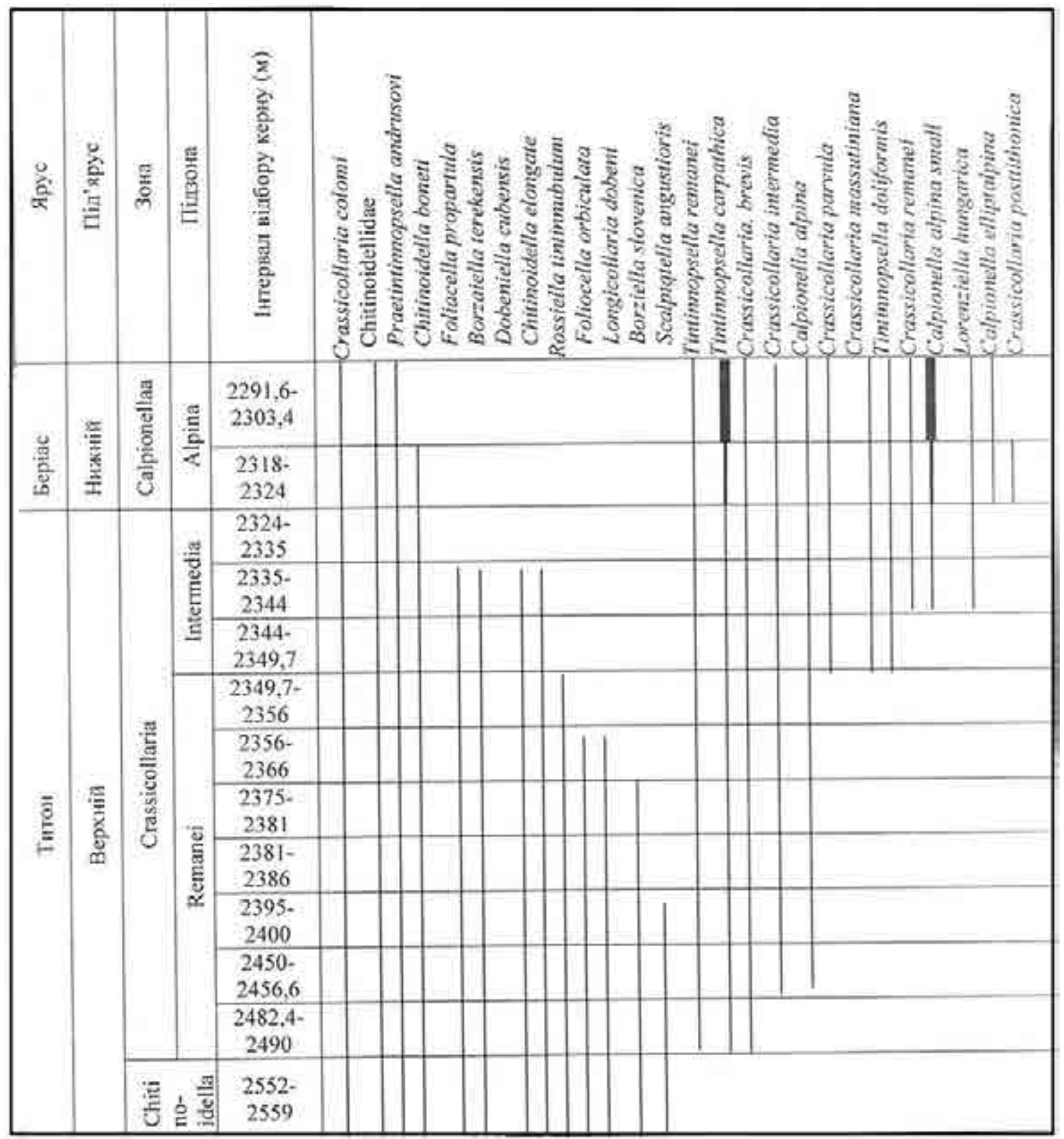

Рис. 5. Поширення тинтинід у розрізі, розкритому свердловиною Моранці-1

Отже, за даними вивчення розрізів Українського Передкарпаття, протягом пізнього титону зміна зональних комплексів тинтинід відбувається поступово, коли в асоціаціях більш молодих біозональних підрозділів присутня невелика кількість видів, характерних для більш давніх, а у верхніх верствах титону з'являються види, типові для крейди. Така закономірність зафріксована також у відкладах Північного Кавказу. В інших регіонах Тетичної палеопровінції дослідники визначають різку зміну зональних комплексів тинтинід. 
Загалом асоціації підзон Remanei та Intermedia Передкарпаття подібні до визначених у цих регіонах, хоча зональні комплекси, описані різними дослідниками, іноді суттєво відрізняються. Так, наявність маленьких сферичних Calpionella alpina у зоні Remanei відзначена лише у Передкарпатті та Західній Сицилії, перша поява красиколярій, тінтінопсел та кальпіонел зафріксована ще у зоні Chitinoidella у Передкарпатті та на Північному Кавказі.

Висновки. У відкладах верхнього титону Середземноморського поясу виділено зони тинтинід Chitinoidella (підзони Dobeni i Boneti), Praetintinnopsella i Crassicollaria. 3a кореляцією з сучасними магнітостратиграфічною та зональною амонітовою шкалами підзона Dobeni відноситься до перехідних верств нижнього і верхнього титону (амонітових зон Ponti та Microcantum), a Boneti - до нижньої частини верхнього титону (нижня половина зони Microcantum), зона Praetintinnopsella залягає у нижніх верствах верхнього титону, зона Crassicollaria відповідає інтервалу амонітових зон - верхній частині зони Micracanthoceras microcanthum, зоні Durandites і нижній частині зони Berriasella Jacobi. У більшості регіонів визначено лише зону Crassicollaria, але критерії виділення та поділу ії відрізняються. Аналіз літературних даних показав, що суттєвою підставою для визначення границі зон Chitinoidella i Crassicollaria $€$ різке зменшення кількості хітиноіделід та збільшення різноманіття і кількості кальпіонелід, серед яких у зоні домінують різні представники роду Crassicollaria, а також Tintinnopsella carpathica i Calpionella alpina. Покрівля зони Crassicollaria визначається за зменшенням різноманіття кальпіонелід, серед яких домінують дрібні Calpionella alpina. На Україні у верхньому титоні Передкарпаття виділено дві підзони зони Chitinoidella і зону Crassicollaria у складі двох підзон - Remanei та Intermedia. Зміна зональних асоціацій у цих відкладах відбувається поступово, коли у більш молодих підрозділах трапляються елементи більш давніх. Так, зональні види зони Chitinoidella майже зникають до кінця підзони Remanei, яка характеризується асоціацією Tintinnopsella carpathica, T. remanei переважно дрібних Calpionella alpina і різних Crassicollaria. У підзоні Intermedia зростає кількість та різноманіття кальпіонелід, збільшується частка великих округлих Calpionella alpina, з'являються види беріасу. Характерні для зони кальпіонеліди переходять у більш молоду зону Calpionella, в підошві якої відбувається різке збільшення кількості C. alpina. Опорний розріз зони Crassicollaria розкрито свердловинами Кароліна-6 і Моранці-1 у Передкарпатському прогині.

\section{СПИСОК ЛІТЕРАТУРИ}

Долицкая И.В. Распространение тинтиннид в верхнеюрских отложениях юго-западного Узбекистана / И.В. Долицкая // Экология и биогеографиия микроорганизмов (фораминиферы, остракоды, радиолярии, наннопланктон) в связи с совершенствованием детальных стратиграфических схем: Тез. докл. IX Всесоюз. микропалеонтологич. совещ. (Ухта, 1983). - Ухта. - 1983. - С. 51-52.

Жабіна Н.М. Біостратиграфія верхньої юри-неокому Українського Передкарпаття за тинтинідами / Н. М. Жабіна // Зб. наук. праць УкрДГРІ. - 2008. - № 3. - С. 56-65.

Жабіна H.M. Верхньоюрська зона тинтинід Chitinoidella та її опорний розріз в Україні» / Н.М. Жабіна // Тектоніка і стратиграфія. - 2014. - Вип. 41. - С. 90-98

Лінецька Л.B. Tintinnoidae, Saccocoma та Globochaete карбонатного мезозою гори Великий Камінець (Бескидова зона Радянських Карпат) / Л.В. Лінецька // Доп. АН УРСР. - Сер.Б.- 1972. - № 1. - С. 17-20.

Линецкая Л.В. Tintinnidae i Radiolaria депрессионной литофации верхнеюрского рифогенного комплекса Предкарпатского прогиба / Л. В. Линецкая, П. Ю. Лозыняк // Палеонт. сб. - 1983. - № 20. - С. 24-28.

Макарьева С.Ф. Дробная стратиграфическая схема верхнего оксфорда-валанжина Северного Кавказа по тинтиннинам / С.Ф. Макарьева // Вопр. микропалеонт. - 1979. - Вып. 22. - С. 50-63.

Grabowski J. Magneto- and biostratigraphy of the Tithonian-Berriasian pelagic sediments in the Tatra Mountains (central Western Carpathians, Poland): sedimentary and rock magnetic changes at the Jurassic-Cretaceous boundary / Grabowski J., Pszczolkowski A. // Cretaceous Research. -2006. - 27. - P. 398-417.

Housa V. Ecological aspects of the evolution of calpionellids (Calpionellidae; Protozoa inc. sed) / Vaclav Housa // Evolution of Calpionellids. - Atti Il Conv. Int. F.E.A. - Pergola, 1990. - P. 357-363. 
Housa V. Correlation of magnetostratigraphy and calpionellid biostratigraphy of the Jurassic-Cretaceous boundary strata in the Western Carpathians / Vaclav Housa, Miroslav Krs, Otakar Man, Petr Pruner and Daniela Venhodova // Geologica Carpathica. - 1999. - Vol. 50, no. 2. - P. 125-144.

Housa V. Combined magnetostratigraphic, paleomagnetic and calpionellid investigations across Jurassic/Cretaceous boundary strata in the Bosso Valley, Umbria, Central Italy/ Housa V., Krs M., Man O., P. Pruner, D. Venhodová; F. Cecca; G. Nardi; M. Piscitello // Cretaceous Research. - 2004. - Vol. 25. - P. 771-785.

Le Hegarat $G$. Tithonique superieur et Berriasien de la bordure cevenole. Correlation des ammonites et des calpionelles / Le Hegarat G., Remane J. // Geobios. - 1968. - № 1. - P. 7-70.

Lukeneder A. High resolution stratigraphy of the Jurassic-Cretaceous boundary interval in the Gresten Klippenbelt (Ausria) / Lukeneder A., Halasova E., Kroh A., Mayrhofer S., Pruner P., Rehakova D., Schnabl P., Sprovieri M., Wagreich M. // Geologica carpathica. - 2010. - Vol.61. -№ 5. - P. 365-381.

Rehakova D. Stratigraphy and microfacies of the Jurassic and lowermost Cretaceous of the Veliky Kamenets section (Pieniny Klippen Belt, Carpathians, Western Ukraine) / Daniela Rehakova, Bronislav A. Matyja, Andrzej Wierzbowski, Jan Schlogl, Michal Krobicki, Marein Barski // Volumna Jurassica. - 2011. - Vol. 9. - P. 61-104.

Remane J. Agreement on the subdivision of the Standars calpionellid zones defined at the IInd planctonic conference, Roma 1970 / J. Remane, D. Bakalova-Ivanova, K. Borza, J. Knauer, J. Nagy, G. Pop, E. Tardi-Filasz // Acta geol. Hungarica. - 1986. - № 29 (1-2). - S. 5-14.

Wimbledon W. A.P. Fixing a basal berriassian and Jurassic/Cretaceous $(\mathrm{J} / \mathrm{K})$ boundary - is there perhaps some light at the end of the Tunnel? / Wimbledon William A.P., Casellato C.E., Rehakova D., Bulot L.G., Erba E., Gardin S., Verreussel Roel M.C.H., Munsterman D.K., Hunt Ch.O. // Rivista Italiana di Paleontologia e Stratigrafia. - 2011. Vol. 117. - no. 2 - P. 295-307.

Wimbledon W.A.P. Resolving the positioning of the Tithonian/Berriasian stage boundary and the base of the Cretaceous System // XII Jurassica Conference. Workshop of the ICS Berriasian Group and IGCP 632. Field Trip Guide and Abstracts Book (ed. J. Michalik and K. Fekete). Earth Science Institute, Slovak Academy of Sciences. Bratislava. - 2016. - P. 128-130.

\section{REFERENCES}

Dolitskaja I.V. Distribution of tintinnides in Upper Jurassic sediments of southwestern Uzbekistan / I.V. Dolitskaya // Ecology and biogeography of microorganisms (foraminifera, ostracods, radiolarians, nannoplankton) in connection with the improvement of detailed stratigraphic schemes: Tethes of reports of the IX All-Union micro-palaeontological meeting (Ukhta, 1983). - Ukhta. - 1983. - P. $51-52$ (in Russian).

Zhabina N.M. Biostratigraphy of the Upper Jurassic-Neocomian of the Ukrainian Precarpathian by Tintinids 1 N.M. Zhabina // Coll. of scientific issues UkrDGRI- 2008. - № 3. - C. 56-65 (in Ukrainian).

Zhabina N.M. Upper Jurassic Tintinnida zone Chitinoidella and its supporting section in Ukraine / N.M. Zhabina /I Tectonics and stratigraphy. - 2014. - № 41. - P. $90-98$ (in Ukrainian).

Linetska L.V. Tintinnoidae, Saccocoma and Globochaete from carbonate Mezozoic of mauntain Veliky Kamenets (Beskid zone of Soviet Carpathions) / Linetska L.V.// Reports AN URSR. - Ser. B.- 1972. - № 1. - P. 17-20 (in Ukrainian).

Linetskaja L.V. Tintinnidae and Radiolaria from depression litofacia of Upper Jurassic reefogenic complex of Precarpathian deflection / L.V.Linetskaja, P. J. Lozunjak // Paleont. col. - 1983. - № 20. - P. 24-28 (in Russian).

Makarjeva S.F. Fractional stratigraphic scheme of the upper Oxford-Valanginian of the North Caucasus by tintinnins //Questions of micropaleont. - 1979. - №. 22. - P. 50-63 (in Russian).

Grabowski J. Magneto- and biostratigraphy of the Tithonian-Berriasian pelagic sediments in the Tatra Mountains (central Western Carpathians, Poland): sedimentary and rock magnetic changes at the Jurassic-Cretaceous boundary / Grabowski J., Pszczolkowski A. // Cretaceous Research. -2006. - 27. - P. 398-417 (in English).

Housa V. Ecological aspects of the evolution of calpionellids (Calpionellidae; Protozoa inc. sed) / Vaclav Housa /I Evolution of Calpionellids. - Atti II Conv. Int. F.E.A. - Pergola, 1990. - P. 357-363 (in English).

Housa V. Correlation of magnetostratigraphy and calpionellid biostratigraphy of the Jurassic-Cretaceous boundary strata in the Western Carpathians / Vaclav Housa, Miroslav Krs, Otakar Man, Petr Pruner and Daniela Venhodova // Geologica Carpathica. - 1999. - Vol. 50, no. 2. - P. 125-144 (in English).

Housa V. Combined magnetostratigraphic, paleomagnetic and calpionellid investigations across Jurassic/Cretaceous boundary strata in the Bosso Valley, Umbria, Central Italy/ Housa V., Krs M., Man O., P. Pruner, D. Venhodová; F. Cecca; G. Nardi; M. Piscitello // Cretaceous Research. - 2004. - Vol. 25. - P. 771-785 (in English). 
Le Hegarat G. Tithonique superieur et Berriasien de la bordure cevenole. Correlation des ammonites et des calpionelles / Le Hegarat G., Remane J. // Geobios. - 1968. - № 1. - P. 7-70 (in English).

Lukeneder $A$. High resolution stratigraphy of the Jurassic-Cretaceous boundary interval in the Gresten Klippenbelt (Ausria) / Lukeneder A., Halasova E., Kroh A., Mayrhofer S., Pruner P., Rehakova D., Schnabl P., Sprovieri M., Wagreich M. // Geologica carpathica. - 2010. - Vol.61. -№ 5. - P. 365-381(in English).

Rehakova $D$. Stratigraphy and microfacies of the Jurassic and lowermost Cretaceous of the Veliky Kamenets section (Pieniny Klippen Belt, Carpathians, Western Ukraine) / Daniela Rehakova, Bronislav A. Matyja, Andrzej Wierzbowski, Jan Schlogl, Michal Krobicki, Marein Barski // Volumna Jurassica. - 2011. - Vol. 9. - P. $61-104$ (in English).

Remane J. Agreement on the subdivision of the Standars calpionellid zones defined at the IInd planctonic conference, Roma 1970 / J. Remane, D. Bakalova-Ivanova, K. Borza, J. Knauer, J. Nagy, G. Pop, E. Tardi-Filasz // Acta geol. Hungarica. - 1986. - № 29 (1-2). - S. 5-14 (in English).

Wimbledon W. A.P. Fixing a basal berriassian and Jurassic/Cretaceous $(\mathrm{J} / \mathrm{K})$ boundary - is there perhaps some light at the end of the Tunnel? / Wimbledon William A.P., Casellato C.E., Rehakova D., Bulot L.G., Erba E., Gardin S., Verreussel Roel M.C.H., Munsterman D.K., Hunt Ch.O. // Rivista Italiana di Paleontologia e Stratigrafia. - 2011. Vol. 117. - no. 2 - P. 295-307 (in English).

Wimbledon W.A.P. Resolving the positioning of the Tithonian/Berriasian stage boundary and the base of the Cretaceous System // XII Jurassica Conference. Workshop of the ICS Berriasian Group and IGCP 632. Field Trip Guide and Abstracts Book (ed. J. Michalik and K. Fekete). Earth Science Institute, Slovak Academy of Sciences. Bratislava. - 2016. - P. 128-130 (in English).

\section{Н.Н. Жабина \\ ВЕРХНИЙ ТИТОН ТЕТИЧЕСКОЙ ПРОВИНЦИИ: ЗОНАЛЬНОСТЬ И КОРРЕЛЯЦИЯ ПО ТИНТИННИДАМ}

Приведены критерии зонального расчленения отложений верхнего титона по тинтиннидам в разрезах Франции, Австрии, Словакии, Польши, Украины, Болгарии, Румынии, Кубы, Італии, Грузии. В регионах Средиземноморского пояса выделены зоны тинтиннид Chitinoidella (подзоны Dobeni $и$ Boneti), Praetintinnopsella и Crassicollaria, которые охарактеризованы по литературным источникам. Согласно корреляции с современными магнитостратиграфической и аммонитовой шкалами подзона Dobeni относится к переходным слоям нижнего и верхнего титона (аммонитовых зон Ponti и Microcantum), a Boneti - к нижней части верхнего титона (нижняя половина зоны Microcantum), зона Praetintinnopsella залегает в низах верхнего титона, зона Crassicollaria соответствует интервалу аммонитовых зон - верхней части зоны Micracanthoceras microcanthum, зоне Durandites и нижней части зоны Berriasella Jacobi. В большинстве регионов установлена только зона Crassicollaria, но критерии ее выделения и подразделения отличаются. Существенным основанием для определения подошвы зоны является резкое сокращение количества хитиноиделлид и увеличение разнообразия и количества кальпионеллид, среди которых в зоне доминируют представители рода Crassicollaria, а также Tintinnopsella carpathica и Calpionella alpina. В кровле зоны сокращается разнообразие кальпионеллид, среди которых преобладают мелкие Calpionella alpina, количество которых резко возрастает в подошве берриаса. В верхнем титоне Предкарпатского прогиба Украины выделены зоны Chitinoidella (подзоны Dobeni, Boneti) и Crassicollaria (Remanei, Intermedia). Изменение зональных ассоциаций в этих отложениях происходит постепенно, когда в более молодых подразделениях присутствуют элементы более древних. Так, характерные виды зоны Chitinoidella почти исчезают до конца подзоны Remanei, которая характеризуется ассоциацией Tintinnopsella carpathica, T. remanei, разных Crassicollaria и преимущественно мелких Calpionella alpina. В подзоне Intermedia возрастает количество и разнообразие кальпионеллид, увеличивается доля больших округлых C. alpina, появляются виды, типичные для берриаса. Характерные для зоны кальпионеллиды переходят в более молодую зону Calpionella, в подошве которой происходит расцвет C. alpina. Приведена детальная характеристика опорного разреза зоны Crassicollaria в Украине.

Ключевые слова: тинтинниды, зональные подразделения, корреляция, верхний титон, Средиземноморский пояс, Карпаты Украины. 


\section{N.M. Zhabina \\ UPPER TITHONIAN IN THE PROVINCE OF TETHYS: ZONATION AND CORRELATION BY TINTINNIDS}

Criterions for the zonation by tintinnids of the Upper Tithonian deposits in the sections of France, Austria, Slovak, Poland, Ukraine, Bulgaria, Rumania, Cuba, Italy, Georgia are given. In the regions of the Mediterranean belt zone Chitinoidella (subsones Dobeni and Boneti), Praetintinnopsella and Crassicollaria are distinguished, and characteristics of these zones are given by the analysis of the literary sources. By the correlation with the magnitostratigraphy and modern geologic scale subzone Dobeni is corresponding with transitional layers of Lower and Upper Tithonian (ammonites zones Ponti and Microcantum), subzone Boneti with the lower part of Upper Tithonian (lower part of Microcantum), zone Praetintinnopsella with the lower layers of Upper Tithonian, zone Crassicollaria with the interval of the ammonites zones - upper part of Micracanthoceras microcanthum, Durandites and lover part of Berriasella Jacobi. In majority of the regions only zone Crassicollaria is distinguished, but the criterions for its subdivision are different. The essential basis for determining of the lover boundary of zone is the sharp decreasing of the number of chitinoidellids and increasing of the variety and number of calpionellids. Crassicollaria, Tintinnopsella carpathica and Calpionella alpina are dominating. In the upper boundary chitinoidellids decreased and the number of small Calpionella alpina very increased in Lower Berriassian. Zones Chitinoidella (subzones Dobeni, Boneti) and Crassicollaria (Remanei, Intermedia) are determined in the Upper Tithonian deposits in Ukrainian Carpathian Foredeep. The changing of zonal associations happened gradually. In more yang subdivisions are present more antique elements. Characteristic specias of the Chitinoidella zone almost disappeared to the end of Remanei subzone. Tintinnopsella carpathica, T. remanei, various Crassicollaria and mostly small Calpionella alpina are peculiar to this one. In subzone Intermedia the abundant of calpionellids and the number of big roundish $C$. alpina increased, and the typical Berriassian specias appeared. Zonal taxons of calpionellids pass on the more yang zone Calpionella, in the lower border of which took place the C. alpina bloom. Detailed characteristic of the Crassicollaria zone strong section in Ukraine is given.

Key wards: tintinnids, zonal subdivisions, correlation, Upper Tithonian, Mediterranean belt, Ukrainian Carpathian.

Інститут геологічних наук НАН України, м. Київ

Наталія Миколаївна Жабіна

E-mail: zhabinanatalia@gmail.com

Стаття надійшла: 12.05.2016 